\title{
Preparation of Simulated Waste Solutions for Solvent Extraction
} Testing

by

R. A. Peterson

Westinghouse Savannah River Company

Savannah River Site

Aiken, South Carolina 29808

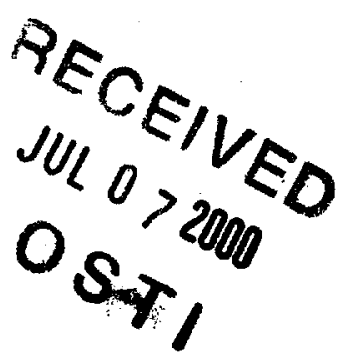

This paper was prepared in connection with work done under the above contract number with the U.S. Department of Energy. By acceptance of this paper, the publisher and/or recipient acknowledges the U. S.

Government's right to retain a nonexclusive, royalty-free license in and to any copyright covering this paper, along with the right to reproduce and to authorize others to reproduce all or part of the copyrighted paper. 


\section{DISCLAIMER}

This report was prepared as an account of work sponsored by an agency of the United States Government. Neither the United States Government nor any agency thereof, nor any of their employees, makes any warranty, express or implied, or assumes any legal liability or responsibility for the accuracy, completeness, or usefulness of any information, apparatus, product or process disclosed, or represents that its use would not infringe privately owned rights. Reference herein to any specific commercial product, process or service by trade name, trademark, manufacturer, or otherwise does not necessarily constitute or imply its endorsement, recommendation, or favoring by the United States Government or any agency thereof. The views and opinions of authors expressed herein do not necessarily state or reflect those of the United States Government or any agency thereof.

This report has been reproduced directly from the best available copy.

Available for sale to the public, in paper, from: U.S. Department of Commerce, National Technical Information Service, 5285 Port Royal Road, Springfield, VA 22161

phone: (800) 553-6847

fax: (703) 605-6900

email: orders@ntis.fedworld.gov

online ordering: http://www.ntis.gov/ordering.htm

Available electronically at http://www.doe.gov/bridge

Available for a processing fee to U.S. Department of Energy and its contractors, in paper, from: U.S. Department of Energy, Office of Scientific and Technical Information, P.O. Box 62, Oak Ridge, TN 37831-0062

phone: (865)576-8401

fax: (865)576-5728

email: reports@adonis.osti.gov 


\section{DISCLAIMER}

Portions of this document may be illegible in electronic image products. Images are produced from the best available original document. 
WSRC-RP-2000-00361, Rev.0

Keywords: Salt processing, High level waste

Retention: Permanent

\section{PREPARATION OF SIMULATED WASTE SOLUTIONS FOR SOLVENT EXTRACTION TESTING}

R.A. Peterson

Publication Date: May 1, 2000 
WSRC-TR-2000-00361 Rev.0

Page 2 of 11

Preparation of Simulated Waste Solutions for Solvent Extraction Testing

Author

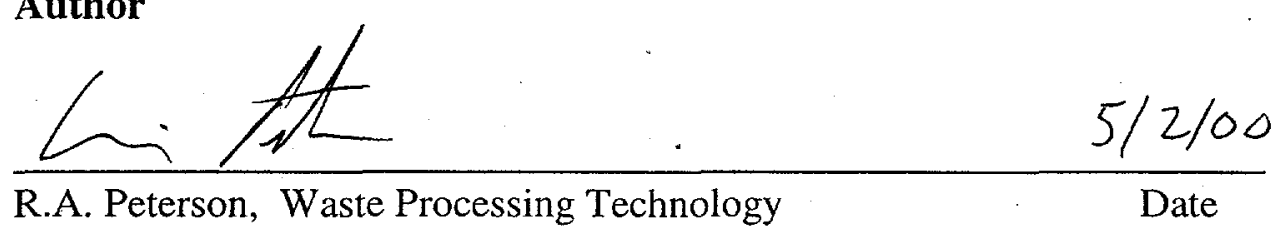

Technical Review

$\frac{\text { Darrel A. Walker }}{\text { D.D. Walker, Waste Processing Technology }} \frac{5 / 2100}{\text { Date }}$

Approvals

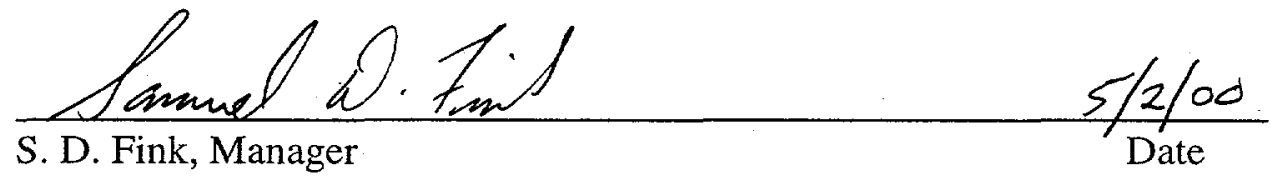

Waste Processing Technology

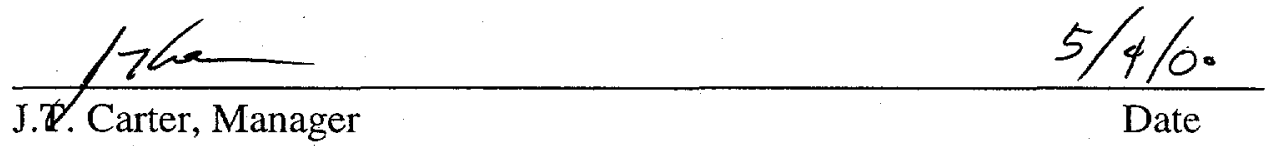

High Level Waste

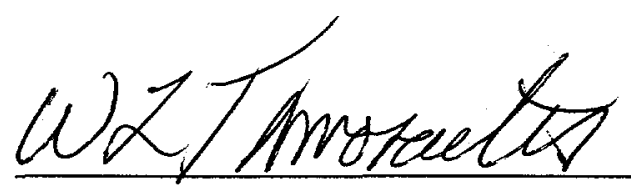

W.L. Tamosaitis. FinkManager Waste Processing Technology 


\section{SUMMARY}

Personnel will need to routinely prepare 0.5 to $10 \mathrm{~L}$ batches of salt solutions simulating Savannah River Site (SRS) soluble waste for solvent extraction testing. This report describes the compositions and preparation methods.

\section{DISCUSSION}

The simulant compositions vary by waste type (e.g., average, high hydroxide, and high nitrate) and by total sodium ion concentration (typically 3 to 7 molar $\mathrm{Na}^{+}$). The waste types represent the average and extreme compositions expected in the feed stream sent to the salt decontamination process. ${ }^{1-2}$ As such, they do not represent the extremes in composition of liquid waste currently in the SRS tank farms. Some blending is expected prior to transfer to the salt decontamination process. The average solution represents a blend of all sotuble waste in the tank farm. The nominal sodium ion concentration is 5.6 molar for the feed to the solvent extraction option for salt disposition.

Table I lists the concentrations of 14 major components. The soluble salt values were derived from the average salt concentration as specified by Dimenna et al. ${ }^{3}$ These average values were produced by analysis of the High Level waste Characterization And Tracking System (HLCATS), the chemical composition database of the Tank Farms. Speedup ${ }^{\text {TM }}$ was used to produce feed compositions for the various options. In doing this, an average feed vector was developed based on the data found in HLCATS. This vector is the best estimate to date of an average feed solution for the various processes. The average feed vector produced a total soluble $\mathrm{Na}+$ concentration of $6.29 \mathrm{M}$. The numbers in the table are the values presented in Tables 2.3-5 through 2.3-7 of the reference 3 adjusted to the new CSEX flowsheet $\mathrm{Na}^{+}$concentration of $5.6 \mathrm{M}$.

Appendix A lists the amounts and identities of chemicals used to prepare 1-L batches at $5.6 \mathrm{M} \mathrm{Na}^{+}$. Small batches of simulants are prepared from reagent or similar purity chemicals.

When high purity chemicals are used in the preparation, typically less than 0.5 grams of solids fail to dissolve per liter of solution. Larger amounts of insoluble solids could be obtained if lower purity chemicals are used in the preparation. For most applications, the solutions are filtered if solids remain after final dilution. The solutions should be cooled to room temperature and aged for at least 24 hours before filtering.

Aluminum nitrate $\left[\mathrm{Al}\left(\mathrm{NO}_{3}\right)_{3} \cdot 9 \mathrm{H}_{2} \mathrm{O}\right]$ is the usual source of aluminate ion. Use of aluminum nitrate requires addition of extra sodium hydroxide and less sodium nitrate based on the following stoichiometry.

$$
\mathrm{Al}\left(\mathrm{NO}_{3}\right)_{3}+4 \mathrm{NaOH}=\mathrm{NaAlO}_{2}+3 \mathrm{NaNO}_{3}+2 \mathrm{H}_{2} \mathrm{O}
$$




\section{TABLE I. Composition of Simulated Waste Solutions}

\begin{tabular}{|c|c|c|}
\hline Component & & Average $(\mathbf{M})$ \\
\hline $\mathrm{Na}^{+}$ & & 5.6 \\
\hline $\mathrm{K}^{+}$ & & 0.015 \\
\hline $\mathrm{Cs}^{+}$ & & 0.00014 \\
\hline $\mathrm{OH}^{-}$ & & 2.06 \\
\hline $\mathrm{NO}_{3}^{-}$ & & 2.03 \\
\hline $\mathrm{NO}_{2}^{-}$ & & 0.50 \\
\hline $\mathrm{AlO}_{2}^{-}$ & & 0.28 \\
\hline $\mathrm{CO}_{3}{ }^{2-}$ & & 0.15 \\
\hline $\mathrm{SO}_{4}^{2-}$ & & 0.14 \\
\hline $\mathrm{Cl}^{-}$ & & 0.024 \\
\hline $\mathrm{F}^{-}$ & & 0.028 \\
\hline $\mathrm{PO}_{4}^{3-}$ & - & 0.007 \\
\hline $\mathrm{C}_{2} \mathrm{O}_{4}{ }^{2-}$ & & 0.008 \\
\hline $\mathrm{SiO}_{3}{ }^{2-}$ & & 0.03 \\
\hline $\mathrm{MoO}_{4}^{2-}$ & & 0.00007 \\
\hline $\mathrm{NH}_{3}$ & & 0.001 \\
\hline
\end{tabular}

Aluminum nitrate yields an acidic solution in water and can react with sodium nitrite to form $\mathrm{NO}_{2}$ gas. Thus, the preferred order of addition is to dissolve sodium hydroxide first, followed by aluminum nitrate. Sodium nitrite is added only after the aluminum nitrate is completely dissolved in excess sodium hydroxide.

If disodium hydrogen phosphate is used instead of trisodium phosphate, additional sodium hydroxide should be added to neutralize the acidic hydrogen.

Appendix B contains an example of instructions for the preparation of a 1-L batch of salt solution (components listed in Appendix A). Salt solutions in volumes $\leq 2 \mathrm{~L}$ are usually prepared in volumetric glassware so that the amount of water required need not be measured. However, the densities of the salt solution has been measured and the required mass of water can be calculated. The density $(\mathrm{g} / \mathrm{mL})$ at $22^{\circ} \mathrm{C}$ is calculated from the total sodium ion concentration (molar) by the following equation. ${ }^{4}$ Note that this density correlation was developed for a slightly different composition of salts. The actual density of the as made salt solution may be slightly different.

$$
\text { Average: } \quad \mathrm{d}(\mathrm{g} / \mathrm{mL})=1.009+0.04454\left[\mathrm{Na}^{+}\right](\mathrm{M})
$$

Trace metals will also be added to the simulant. The metals may cause additional degradation of the solvent system and as such should be included in all simulant testing. 
Table II contains the concentrations of the metals needed. Appendix $\mathrm{C}$ lists the amounts and identities of chemicals used to prepare 1-L batches of each waste type at $5.6 \mathrm{M} \mathrm{Na}^{+}$. These chemicals are added from prepared concentrated stock solutions.

\section{Table II}

\section{Soluble Metals}

\begin{tabular}{|c|c|}
\hline Component & $\begin{array}{c}\text { Concentration } \\
(\mathrm{mg} / \mathrm{L})\end{array}$ \\
\hline Copper & 1.44 \\
\hline Chromium & 75 \\
\hline Ruthenium & 0.82 \\
\hline Palladium & 0.41 \\
\hline Rhodium & 0.21 \\
\hline Iron & 1.44 \\
\hline Zinc & 8 \\
\hline Tin & 2.4 \\
\hline Mercury & 0.05 \\
\hline Lead & 2.1 \\
\hline Silver & 0.01 \\
\hline
\end{tabular}

The values for the soluble metals are based on data obtained for Tank $48 \mathrm{H}$ during the analysis of the tetraphenylborate decomposition that occurred in late 1995 and early 1996 at ITP startup. ${ }^{5}$ With the exception of chromium, all of the values in Table II are higher (3-10X) than would be predicted by the HLCATS database. ${ }^{3}$ However, since these values are well documented and occurred in plant processing, they have been chosen for the simulant composition. They are not bounding but represent values that could be expected over the life of the plant.

Table III provides a list of organic components that will also be added to the salt solution.

Table III

Organic Components

\begin{tabular}{|c|c|}
\hline Component & $\begin{array}{c}\text { Concentration } \\
(\mathrm{mg} / \mathrm{L})\end{array}$ \\
\hline tri-n-Butyl Phosphate (TBP) & 0.5 \\
\hline di-n-Butyl Phosphate (DBP) & 25 \\
\hline $\begin{array}{c}\text { mono-n-Butyl Phosphate } \\
\text { (MBP) }\end{array}$ & 25 \\
\hline$n$-Butanol & 2 \\
\hline Formate & 1500 \\
\hline tri-Methylamine & 10 \\
\hline
\end{tabular}

The primary constituents of the organics in the waste tanks are byproducts of the hydrolysis of TBP. The solubility of TBP has been shown to be approximately $1.1 \mathrm{mg} / \mathrm{L}$ 
under alkaline condtions. ${ }^{6}$ The DBP, MBP and $\mathrm{n}$-butanol are very soluble in salt solutions. The values presented in Table III are estimates based on prior results ${ }^{3}$, Many trace organics are not dilineated. Most of the resin organics processed into the Tank Farm appear in very small quantities and should be pursued separately, but not included in the simulant to be employed for all tests. .

\section{REFERENCES}

1. P. L. Rutland et al., "Bases, Assumptions, and Results of the Flowsheet Calculations for the Initial Eighteen Salt Disposition Alternatives", WSRC-RP-98-00166, 25 June 1998.

2. D. D. Walker, "Modeling of Crystalline Silicotitanate Ion Exchange Columns," WSRC-TR-98-00343, Rev.0, October 2, 1998.

3. R. A. Dimenna, et al., "Bases, Assumptions, and Results of the Flowsheet Calculations for the Decision Phase Salt Disposition Alternatives," WSRC-RP-99-00006, Rev. 0, $9 / 30 / 99$

4 D. D. Walker and G. K. Georgeton, "Viscosity and Density of Simulated Salt Solutions," WSRC-RP-89-1088, October 19, 1989.

5. D. D. Walker, et al., "Decomposition of Tetraphenylborate in Tank 48H (U)", WSRCTR-96-0113, May 10, 1996.)

6. R. F. Swingle, "Evaluation of the Solubility of Tributyl Phosphate in ITP Salt Solutions", WSRC-RP-93-1397, December 13, 1993.

7. WSRC-TR-00091, Tank 39 Acceptance of Canyon Waste, Draft in preparation 
Appendix A. Average Salt Solution (1-L batch)

\begin{tabular}{|c|c|c|c|c|}
\hline Component & $\underline{\text { Source }}$ & $\begin{array}{l}\text { Molecular } \\
\text { Weight } \\
\text { (g/mole) }\end{array}$ & $\begin{array}{c}\text { Target } \\
\text { Concentration } \\
\text { (molar) }\end{array}$ & $\begin{array}{l}\text { Amount } \\
\text { Required } \\
\text { (g) }\end{array}$ \\
\hline $\mathrm{K}^{+}$ & $\mathrm{KNO}_{3}$ & 101.1 & 0.015 & 1.517 \\
\hline $\mathrm{Cs}^{+}$ & $\mathrm{CsCl}$ & 168.37 & 0.00014 & 0.024 \\
\hline $\mathrm{OH}^{-}$ & $\mathrm{NaOH}$ & 40.00 & 2.06 & 127.48 \\
\hline $\mathrm{NO}_{3}^{-}$ & $\mathrm{NaNO}_{3}$ & 84.99 & 2.03 & 99.85 \\
\hline $\mathrm{NO}_{2}^{-}$ & $\mathrm{NaNO}_{2}$ & 69.00 & 0.50 & 34.50 \\
\hline $\mathrm{AlO}_{2}^{-}$ & $\mathrm{Al}\left(\mathrm{NO}_{3}\right)_{3} \cdot 9 \mathrm{H}_{2} \mathrm{O}$ & 375.14 & 0.28 & 105.04 \\
\hline $\mathrm{CO}_{3}^{2-}$ & $\mathrm{Na}_{2} \mathrm{CO}_{3} \cdot \mathrm{H}_{2} \mathrm{O}$ & 124.01 & 0.15 & 18.6 \\
\hline $\mathrm{SO}_{4}^{2-}$ & $\mathrm{Na}_{2} \mathrm{SO}_{4}$ & 142.04 & 0.14 & 19.89 \\
\hline $\mathrm{Cl}^{-}$ & $\mathrm{NaCl}$ & 58.44 & 0.024 & 1.403 \\
\hline $\mathrm{F}^{-}$ & $\mathrm{NaF}$ & 41.99 & 0.028 & 1.176 \\
\hline $\mathrm{PO}_{4}{ }^{3-}$ & $\mathrm{Na}_{2} \mathrm{HPO}_{4} \cdot 7 \mathrm{H}_{2} \mathrm{O}$ & 268.09 & 0.007 & 1.877 \\
\hline $\mathrm{C}_{2} \mathrm{O}_{4}{ }^{2-}$ & $\mathrm{Na}_{2} \mathrm{C}_{2} \mathrm{O}_{4}$ & 134.00 & 0.02 & 2.680 \\
\hline $\mathrm{SiO}_{3}{ }^{2-}$ & $\mathrm{Na}_{2} \mathrm{SiO}_{3} \cdot 9 \mathrm{H}_{2} \mathrm{O}$ & 284.2 & 0.03 & 8.526 \\
\hline $\mathrm{MoO}_{4}{ }^{2-}$ & $\mathrm{Na}_{2} \mathrm{MoO}_{4} \cdot 2 \mathrm{H}_{2} \mathrm{O}$ & 241.95 & 0.00007 & 0.017 \\
\hline $\mathrm{NH}_{3}$ & $\mathrm{NH}_{4} \mathrm{NO}_{3}$ & 80 & 0.001 & 0.080 \\
\hline Vate & & & & 835.8 \\
\hline
\end{tabular}

Total weight: 1258 . 


\section{Appendix B \\ Instructions for Preparation of Salt Solution}

Note: Appendix A contains a listing the chemicals required for this simulant. The following information should be recorded for each species: operator name, date, balance identification, manufacturers and lot numbers for each chemical).

1. Locate and label a clean, dry, 1-L volumetric flask. Weigh it empty and dry. The vessels shall be washed and thoroughly rinsed to remove all traces of contaminants (e.g., oils, surfactants, etc.).

Do not use a glass vessel so as to avoid leaching of elements from the glass by the highly alkaline solution.

If a large quantity of simulant is being prepared use a mixer of a size suitable for the preparation task. Loosely cover the mixing vessel with plastic, that is taped to the outside of the mixing vessel and that will allow condensed water vapor to collect near the center of the plastic cover and return to the mixing vessel.

2. Weigh the $\mathrm{NaOH}$ into the flask. Add $\mathrm{g}$ of water and dissolve the $\mathrm{NaOH}$ before continuing.

Caution: Dissolving $\mathrm{NaOH}$ will heat the solution. If the solution becomes too hot to handle safely, cool it before proceeding.

Note: If the solution is not prepared in a volumetric flask (e.g., if the water is added by weight rather than by filling to the line on the flask), keep the container closed as much as possible when the solution is hot to avoid evaporation of water. If using volumetric glassware, reserve a portion of the water for the final addition in step 6 .

3. Add the aluminum nitrate to the flask and mix to dissolve.

Caution: Do not add sodium nitrite prior to dissolving the aluminum nitrate in excess $\mathrm{NaOH}$. Poisonous red fumes of $\mathrm{NO}_{2}$ could form.

4. Add the remaining chemicals.

The additional chemicals should be added slowly and with continuous mixing.

For the addition of $\mathrm{F}, \mathrm{PO}_{4}^{3}, \mathrm{C}_{2} \mathrm{O}_{4}^{2-}$, and $\mathrm{SiO}_{3}^{2-}$ premix each reagent $(\mathrm{NaF}$, $\mathrm{Na}_{2} \mathrm{HPO}_{4} \cdot 7 \mathrm{H}_{2} \mathrm{O}, \mathrm{Na}_{2} \mathrm{C}_{2} \mathrm{O}_{4}$, and $\mathrm{Na}_{2} \mathrm{SiO}_{3} \cdot 9 \mathrm{H}_{2} \mathrm{O}$ ) as individual solutions in a small quantity of water to totally dissolve them prior to adding to the above salt solution. Add the $\mathrm{Na}_{2} \mathrm{SiO}_{3} \cdot 9 \mathrm{H}_{2} \mathrm{O}$ solution very slowly with good mixing to avoid local precipitation. Add the other solutions slowly with thorough mixing.

Use $\mathrm{NH}_{4} \mathrm{NO}_{3}$ to provide the required amount of ammonia. Extreme caution should be employed when adding the ammonium nitrate. Poisonous and flammable ammonia gas may evolve from solution upon addition 
Add the soluble metal components in the following order:
a. $\mathrm{Cr}$
b. $\mathrm{Sn}$
c. $\mathrm{Hg}$
d. $\mathrm{Cu}$
e. $\mathrm{Rh} / \mathrm{Pd} / \mathrm{Ag} / \mathrm{Ru}$
f. $\mathrm{Zn} / \mathrm{Pb} / \mathrm{Fe}$

The reason for this suggestion is to minimize the possibility of irreversible sorption of metals on the more insoluble metal hydroxides that may be present in the solution. Some of these metals may precipitate and the simulant will need to be filtered after it is allowed to come to equilibrium. After filtration, the simulant must be analyzed to confirm the concentrations of soluble metals.

5. Mix to dissolve (1-2 hours).

6. Allow the solution to cool to room temperature.

Note: If using volumetric glassware, fill to the line with water after cooling.

7. Reweigh the solution and compare to the expected weight. If the weights differ significantly, investigate for a missing component or error in weighing.

8. Allow the solution to age at least 24 hours.

Note: The solution should equilibrate long enough after preparation to avoid concerns from slow precipitation. For volumes as large as $10 \mathrm{~L}, 24$ hours generally provides adequate equilibration time. The best practice will include a second hold period and a second filtration.

9. Filter the solution through any convenient filter (medium frit sintered glass is acceptable).

10.

11. Submit a sample of the filtered simulant for QA analysis of composition. 
Appendix C.

Table II. Metal Concentrations

\begin{tabular}{|c|c|c|c|c|c|c|c|c|c|}
\hline & Compound & $\begin{array}{l}\text { Molec. wt } \\
\text { (g/mole) }\end{array}$ & $\begin{array}{l}\text { Metal wt. } \\
\text { (g/mole) }\end{array}$ & $\begin{array}{l}\text { Stock } \\
\text { Soln. } \\
\text { vol } \\
\text { (mL) }\end{array}$ & Solvent & $\begin{array}{l}\text { Quantity } \\
\text { of salt } \\
\text { used }(g)\end{array}$ & $\begin{array}{l}\text { Stock } \\
\text { Metal } \\
\text { Conc. } \\
\text { (mg/L) }\end{array}$ & $\begin{array}{l}\text { Nominal } \\
\text { Conc. } \\
\text { (mg/L) }\end{array}$ & $\begin{array}{l}\text { Volume to } \\
\text { Add for } 1 \mathrm{~L} \\
\text { Test (mL) }\end{array}$ \\
\hline $\mathrm{Cu}$ & $\mathrm{Cu}\left(\mathrm{SO}_{4}\right) \cdot 5 \mathrm{H}_{2} 0$ & 249.68 & 63.546 & 100 & Water & 1.10 & 2806 & 1.4 & 0.5 \\
\hline $\mathrm{Cr}$ & $\mathrm{Na}_{2} \mathrm{CrO}_{4}$ & 161.97 & 51.9961 & 100 & $0.1 \mathrm{M} \mathrm{NaOH}$ & 23.3639 & 75088 & 75 & 1.0 \\
\hline $\mathrm{Zn} / \mathrm{Pb} / \mathrm{Fe}$ & $\begin{array}{l}\mathrm{Zn}\left(\mathrm{NO}_{3}\right)_{2} \bullet 6 \mathrm{H}_{2} \mathrm{O} \\
\mathrm{Pb}\left(\mathrm{NO}_{3}\right)_{2} \\
\mathrm{Fe}\left(\mathrm{NO}_{3}\right)_{3} \bullet 9 \mathrm{H}_{2} \mathrm{O}\end{array}$ & $\begin{array}{l}297.47 \\
331.2 \\
404.0 \\
\end{array}$ & $\begin{array}{l}64.39 \\
207.2 \\
55.847 \\
\end{array}$ & 100 & $0.1 \mathrm{M} \mathrm{HNO}_{3}$ & $\begin{array}{l}3.6422 \\
0.3352 \\
1.0421 \\
\end{array}$ & $\begin{array}{l}8017 \\
2100 \\
1442 \\
\end{array}$ & $\begin{array}{l}8.0 \\
2.1 \\
1.44 \\
\end{array}$ & 1.0 \\
\hline $\mathrm{Sn}$ & $\mathrm{SnCl}_{2} \cdot 2 \mathrm{H}_{2} \mathrm{O}$ & 225.63 & 118.71 & 100 & $0.1 \mathrm{M} \mathrm{HNO}_{3}$ & 0.4563 & 2403 & 2.4 & 1.0 \\
\hline $\mathrm{Hg}$ & $\mathrm{Hg}\left(\mathrm{NO}_{3}\right) \cdot \mathrm{H}_{2} \mathrm{O}$ & 342.61 & 200.59 & 100 & $0.1 \mathrm{M} \mathrm{HNO}_{3}$ & 0.0854 & 500.7 & 0.05 & 0.1 \\
\hline $\mathrm{Rh} / \mathrm{Pd} / \mathrm{Ag} / \mathrm{Ru}$ & $\begin{array}{l}\mathrm{Rh}\left(\mathrm{NO}_{3}\right)_{3} \\
\mathrm{Pd}\left(\mathrm{NO}_{3}\right)_{2} \\
\mathrm{AgNO}_{3} \\
\mathrm{RuCl}_{3} \bullet \mathrm{xH}_{2} \mathrm{O}\end{array}$ & 169.87 & $\begin{array}{l}4.93 \% \\
15.27 \% \\
107.868 \\
41.74 \% \\
\end{array}$ & 100 & $0.1 \mathrm{M} \mathrm{HNO} 3$ & $\begin{array}{l}4.2609 \\
2.6872 \\
0.0157 \\
1.9645 \\
\end{array}$ & $\begin{array}{l}2106 \\
4109 \\
100 \\
8210 \\
\end{array}$ & $\begin{array}{l}0.21 \\
0.41 \\
0.01 \\
0.82 \\
\end{array}$ & 0.1 \\
\hline
\end{tabular}


CC: J.T. Carter, 704-3N

H.D. Harmon, 704-3N

H.H. Elder, 704-S

S.D. Fink, 773-A

F.F. Fondeur, 773-A

J.R. Fowler, $704-3 \mathrm{~N}$

G.A. Taylor, $704-196 \mathrm{~N}$

R.T. Jones, $704-3 \mathrm{~N}$

D.T. Hobbs, 773-A

J.M. Reynolds, $704-196 \mathrm{~N}$

STI, 703-43A
L.M. Nelson, 773-43A

R.A. Peterson, 773-A

K.J. Rueter, $704-3 \mathrm{~N}$

P.L. Rutland, 704-196N

P.C. Suggs, 704-196N

W.L. Tamosaitis, 773-A

R.A. Jacobs, 704-3N

D.D. Walker, 773-A

M.G. Schwenker, 703-46A

J.W. McCullough, 704-3N

LWPG Files, c/o Cathy Canada, 773-A 